\title{
A GYERMEKI TANÚVALLOMÁSOK ÉS A FELNŐTTEK IGAZSÁGA EGY CSALFA VILÁGBAN
}

\section{CHILDREN'S DEPOSITIONS AND THE ADULT'S VERITY IN A DECEPTIVE WORLD}

\author{
Dósa Zoltán ${ }^{1^{*}}$ \\ ${ }_{1}$ Pedagógia és Alkalmazott Didaktika Intézet, Babeș-Bolyai Tudományegyetem, Kolozsvár \\ https://doi.org/10.47833/2020.1.ART.002
}

\section{Kulcsszavak: \\ gyermeki tanúvallomás \\ igazmondás \\ hazugság \\ kompetencia vizsgálat}

\section{Keywords:}

children's depositions

truth-telling

lying

competence examination

\section{Cikktörténet:}

Beérkezett 2019. október 25.

Átdolgozva 2020. január 17.

Elfogadva 2020. január 25.

\begin{abstract}
Összefoglalás
A gyermeki tanúvallomások megbízhatósága fontos kérdése az igazságszolgáltatásnak. A gyermek életkorának elöre haladtával és fogalmi ismereteinek gazdagodásával egyidőben észlelhető, hogy nő az elvárásuk az igaz tartalmak iránt, és egyre inkább hajlanak arra, hogy elítéljék a hazugságot. A gyermekek tanúvallomásának két lényeges pontja, hogy tudják-e, hogy mi az igaz és hamis vagy valós és valótlan közötti különbség, illetve, hogy betartják-e a szavukat, amikor megígérik, hogy csak az igazat fogják mondani. Felmerülhet annak a lehetősége, hogy nem tudják az igaz és hamis közötti különbséget, ennélfogva nem várható el, hogy csak igazat szóljanak, de az is előfordulhat, hogy igenis értik a kettő közötti különbséget, de ennek ellenére nem mondanak igazat.
\end{abstract}

\begin{abstract}
The reliability of children's depositions has major implications for legal systems. With regard to children's conceptual knowledge about truth- and lie-telling we can confirm that as age increases they become more inclined to recommend that others tell the truth, and more likely to give negative ratings to acts of lying. Using competence examinations to screen out children with limited understanding of lie- and truth-telling is problematic. Furthermore, children's understanding lie- and truth-telling conceptually does not relate to their actual truthfulness. Asking children to promise to tell the truth, has some real value, although it does not eliminate lying in all children.
\end{abstract}

\section{Bevezetés}

Ahhoz, hogy értsük a gyermek világképét, fel kell térképeznünk a valóságot is, ami a kibontakozó elmét tartalommal tölti fel. Ez a valóság nem a felnőtti valóság valamely töredéke, vagy zsugorított mása, hanem egy sajátos reprezentáció, ami a sajátos megismerésből fakad. A gyermek nem láthatja olyannak a világot mint a felnőtt, mert ehhez nem áll rendelkezésére olyan kognitív apparátus mint a nagyoknak. A gyermeki szemmel látott világ is valóságosnak tekinthető, de nem úgy valóságos, mint a felnőtt világ.

\footnotetext{
* Kapcsolattartó szerző. telefon: 0040-745-028987

E-mail cím: zoltan.dosa@ubbcluj.ro
} 
Ha a valóságos és nem valóságos vagy igaz és hamis közötti határt feszegetjük, akkor a probléma még jobban elmélyül, mert a gyermeki korlátozott megismerésből fakadóan ezek fogalmi megértése különbözhet a felnőttekétöl, de számolnunk kell azzal is, hogy egy társas térben ennek morális implikációi is vannak.

\section{2. Értelmesség és csalás az élet hajnalán}

Az óvodáskort gyakran nevezik a kényszererkölcs időszakának is, mivel ekkor az erkölcsi ítéletek a felnőttek elvárásait követik, egyszerüen szólva az a jó és rossz, amit a felnőtt annak tart. Ha a gyermek tudatos megtévesztésre törekszik, akkor nemcsak a megtévesztő viselkedését kell felépítenie, verbális és nem verbális jelzéseit szinkronizálnia, hanem azt is fel kell mérnie, hogy milyen erkölcsi következményei lehetnek az esetleges lelepleződésnek. Ez így együttesen eléggé komplex feladat, ennélfogva a köznapi cselekvésekhez viszonyítva többletintelligenciát igényel. Talán nem túlzás, ha azt mondjuk, hogy egy jól megtervezett és kivitelezett gyermeki csalás tulajdonképpen a gyermek értelmességének felső határait jelzi. Úgy is fogalmazhatnánk, hogy abban a szocializációs közegben, amelyikben a megtévesztés müködik, létezni fog egy olyan potenciális fejlődési tér, amelyben az aktuális képességek meghaladhatóak.

Lev Vigotszkij, a neves orosz pszichológus az aktuális fejlődési szint és a potenciális fejlődési szint közötti rést, vagyis a potenciális fejlődési teret a legközelebbi fejlődési zóna fogalmával írta le, melynek lényege, hogy minden felsőrendű pszichikus funkció kétszer bukkan fel az egyedfejlődésben, egyszer a felnőttek irányításával egy kollektív tevékenységben, majd ezt követően a gyermek önálló tevékenységében [1]. Mivel a megtévesztés is csupán a kollektív tevékenységben nyer értelmet, és a felnőttek mindennemü kapcsolatára jellemző, a gyermekek a szocializáció során, mintegy „belenövéssel” elsajátítják ennek fortélyait. A kollektíva tehát, gyakorlatilag akarvaakaratlanul, a gyermeket bevezeti a cselszövések birodalmába, és felkészíti őt egy ilyesfajta hadviselésre is.

A modern intelligenciaelméletekben a neves Robert Sternberg háromívü elméletének van egy olyan összetevője, amiben a tudatos megtévesztés mint intelligens cselekvés könnyen megragadható [2]. A kutató szerint az intelligencia három összetevőjének egyike a komponenciális aspektus. Ez olyan müködési elem, ami az analitikus gondolkodást foglalja magába, és elemző gondolkodást jelent. Aki ebben jó, az jól old meg hagyományos intelligenciateszteket. A következő összetevő a tapasztalati aspektus, ami azt jelenti, hogy az ebben erős személy a tapasztalatainak különböző elemeit ésszerüen és sikeresen kombinálja, ez akár újszerü dolgok létrehozásában is segítheti, így az ilyen embert kreatívnak látjuk. A harmadik összetevő pedig a kontextuális aspektus, ami leginkább a mindennapi élet gyakorlati feladataiban mutatkozik meg, s azt jelenti, hogy a személy sikeresen manipulálja környezetét, illetve jól ismeri és kihasználja az itt müködő szabályokat.

E három komponens együttesen kifejezi a személy általában vett értelmességét, de ezek fejlettségi szintje egyenként különbözhet. A megtévesztő viselkedésben nyilvánvalóan a kontextuális összetevőnek van rendkívüli szerepe, hiszen a környezet sikeres manipulációja függ ettől. Előfordulhat, hogy egy személy intelligenciája a komponenciális és tapasztalati összetevőkben elmarad az életkorára jellemző átlagtól, de társas környezetében jól elboldogul, sőt sikeresnek mondható az emberi kapcsolatokban felmerülő problémák megoldásában. Sternberg anekdotaszerü példaként említi, hogy gyakorló pszichológusi pályája során alkalma adódott egy zárt intézetben értelmi fogyatékos gyermekekkel foglalkozni. Az értelmi fogyatékosnak diagnosztizált személyek valóban nagyon gyengén teljesítettek a klasszikus intelligenciatesztekben, viszont igen körmönfont 
szökési kísérleteik voltak. Méltán merül fel ilyenkor az emberben a kérdés, hogy aki mások tudatos megtévesztésére irányuló bonyolult tervet tud kidolgozni, az értelmi fogyatékosnak tekinthető-e? Az ilyen jellegű esetek rávilágítanak az intelligens viselkedés összetettségére.

Van viszont egy olyan árnyalatuk is, ami kevéssé tudatosul bennünk. Arról van szó, hogy hajlunk arra, hogy csupán a jóra tekintsünk úgy, mint intelligens megnyilvánulásra. $A$ klasszikus vagy akár köznapi értelmezésben, az intelligens viselkedés holdudvarába nemcsak hatékony, hanem morális szempontból is kifogásolhatatlan cselekedetek kerülnek be. Ezen logika szerint, ami intelligensnek minősül az jó, ami nem intelligens az rossz. Viszont ez nem igaz. Az alábbi kis történet remek példa arra, hogy lehet elmés is a bünözés. Egy háromtagú, fiatal afroamerikai srácokból álló tolvajbanda egy „áruval” megpakolt autóval próbált eltűnni Boston egyik fehérek lakta negyedéből, amikor szembejött velük egy rendőrautó. Amint a rendőrök észrevették, hogy gyanús feketék vannak olyan helyen, ahol nem lenne mit keresniük, azonnal megfordultak, hogy üldözőbe vegyék őket. Mielőtt a rendőrök félrehúzatták volna őket, a fekete srácok egyike azonnal leállította az autót, kiugrott, és leintette a rendőrautót. Makogva megkérdezte, hogy hogyan lehet kijutni ebböl a városrészből Roxbury fele, mire a rendőrök részletesen elmagyarázták neki, hogy hol kell haladniuk. Aztán mindenki ment a maga dolgára. Íme, a tolvajok nagyon hamar átkeretezték a rendőrök sejtését: a bűnözőből eltévedt szerencsétlenekké vedlettek át, és megmenekültek [3].

Valójában a félrevezetés, a rosszindulat, vagy egyenesen a gonoszság is lehet értelmességgel telített, ezért valószínüleg az intelligens viselkedés teljesebben megérthető, ha annak morális vonatkozásait figyelmen kívül hagyjuk. Az erkölcs kényszerítő erejét egyébként sem lehet könnyen mérni, mert nem uniformizált hatás, vagyis sok embernek sokfélét jelenthet egy olyan felszólítás, hogy „szeresd felebarátodat” vagy "ne próbáld becsapni a felebarátodat". Persze az életben akadhat bőven olyan helyzet, amikor az értelmesség és a morális elkötelezettség közötti kapcsolat megértése igen hasznos lenne. Ez különösen igaz akkor, amikor gyermekek szavainak kell hitelt adni, és eldönteni, hogy igazat mondanak-e vagy sem.

\section{Az igazság súlya mérlegen}

A kérdés valódi súlyát legtisztábban talán azok a bírósági esetek bizonyítják, amelyekben gyermekeket használnak tanúként. A gyermekek tanúként történő kihallgatása a bírósági pereken az utóbbi évtizedekben igen elterjedtté vált. Az Egyesült Államokban például a kétezres évektöl kezdődően évente több mint 100.000 gyermek tesz tanúvallomást, sajnos zömében olyan kényes ügyekben, amelyekben felnőtt szemtanúk hiányában ők kizárólagos tanúként szerepelnek, és szexuálisan vagy egyéb módon bántalmazták őket [4]. A gyermekek tanúvallomásának két lényeges pontja van. Egyrészt, hogy tudják-e, hogy mi az igaz és hamis vagy valós és valótlan közötti különbség, másrészt, hogy betartják-e a szavukat, amikor megígérik, hogy csak az igazat fogják mondani.

Felmerülhet annak a lehetősége, hogy nem tudják az igaz és hamis közötti különbséget, ennélfogva nem várható el, hogy csak igazat szóljanak, de az is előfordulhat, hogy igenis értik a kettő közötti különbséget, de ennek ellenére nem mondanak igazat. Természetesen a fogalmi megértés vizsgálatánál a kisgyermekek esetében kerülendőek az olyan jellegű elvont kérdések, hogy mit jelent szerinted az igazság vagy mit jelent hazudni. Ehelyett a konkrét és ismerős helyzetleírások mentén megfogalmazott vélemények tisztázhatják a fogalmi elsajátítás szintjét.

Az amerikai bíróságokon a kiskorúak tanúvallomását megelőzi egy úgynevezett kompetencia vizsgálat, ahol pontosan ilyen konkrét történeteket használnak [5]. Az egyik történetben egy Kati nevü kislány elfogyaszt egy csokoládét, annak ellenére, hogy ezt az óvónénije megtiltotta neki. Amikor az óvónéni visszatér, megkérdi: „Kati, megetted a 
csokidat?”. Ezen a ponton a gyermeknek kell válaszolnia: „Mit fog Kati mondani?”. A következő lépésben azt mondják a gyermeknek, hogy Kati tagadni fogja, hogy megette a csokit. Újra megkérdik a gyermeket: „Kati most igazat mondott vagy hazudott?”, „Amit mondott Kati, az jó vagy rossz szerinted?”, „Miért gondolod, hogy jó/rossz?” és „Amit mondott, az kissé jó/rossz vagy nagyon jó/rossz?". A második történet egy elképzelt szituáció, ahol a maga a gyermek a szereplő: „Gondolj arra, hogy otthon vagy és egy üveggel játszol. Anyukád rád szól, hogy ne játssz vele. Amikor kilépik a szobából, te elejted az üveget, és sajnos eltörik. Anyu visszajön és megkérdi, hogy ki tette ezt. Mit válaszolnál rá? Miért?" Figyelembe véve azt, hogy a kisgyermekek gondolkodása igen erősen kötődik a megfigyelhető és tapasztalható konkrétumokhoz, bizonyosra vehető, hogy jobban megértik így a kérdést, mint absztrakt formában, és könnyebben fogalmazzák meg véleményüket.

Az igazmondás szándéka szintén konkrét helyzetben érhető tetten a legkönnyebben. Erre tökéletesen alkalmasak a korábban már bemutatott „ellenállás a kísértésnek” típusú vizsgálatok, amelyekben a gyermekek egy kis csalással könnyen megleshetik az elrejtett Micimackót a kísérletvezető távollétében [6]. Victoria Talwar és munkatársai az egyik kísérletüket úgy tervezték, hogy fogalmi megértést és „ellenállás a kísértésnek” típusú helyzeteket váltakoztattak, vagyis az első helyzetben előbb volt az „ellenállás a kísértésnek”, és azt követte az igazság és hazugság fogalmainak megbeszélése, míg a másikban fordított sorrendben [7]. A sorrendiség azért lehet fontos, mert így ellenőrizhető, hogy az explicit felszólítás az őszinteségre milyen hatással van a valós helyzetben tanúsított viselkedésre. Érdekes módon a sorrendnek nem volt semmilyen szignifikáns hatása, és a gyermekek több mint négyötöde mindkét csoportban csalt, amikor Micimackót nem szabadott volna meglesnie. Egyes gyermekek az igazság és hazugság fogalmait pontosan körülírták, de mégis hazudtak, hogy ne derüljön ki, hogy lestek. Ez olyasmit jelent, hogy nem elég a jót tudni a jót tevéshez, az erkölcsi normák ismerete nem elegendő az erkölcsös viselkedéshez.

A következő lépés viszont az volt, hogy explicit felszólították a gyermekeket arra, hogy csak igazat mondjanak. Ebben a csoportban lett az igazmondás a leggyakoribb. A vizsgálatot összegezve, a 3-7 éves gyermekeknél az igazmondás leghatásosabb módja az, hogyha a felnőttek explicitté teszik azon elvárásukat, hogy az igazat szeretnék hallani. Mindez persze alátámasztja a klasszikus fejlődéselméletek azon állítását is, hogy az erkölcs forrása ebben az életkorban hangsúlyozottan külső eredetű és tekintélyelvű. Váci Mihály ismert verssorait is használhatnánk tanulságként, miszerint: „nem elég a jóra vágyni, la jót akarni kell!/ és nem elég akarni, de tenni, /tenni kell...”. A gyermekek esetében ez úgy válik teljessé, hogy a „kell” felszólításokat egy felnőtt szájába adjuk.

A civilizált országok legtöbbjében, ahol a gyermekek tanúvallomást tehetnek, ez a felkérés explicit formában meg is történik. Mivel az Észak-Amerikában zajló perekben a legnyitottabbak a bírák a gyermeki tanúvallomásokra, ezért nem véletlen, hogy az ebben a jogrendben kidolgozott eljárás a legkörültekintöbb és kidolgozottabb. Itt alapos kompetenciavizsgálat előzi meg a kiskorúak tanúvallomását és figyelmeztetik is őket az igazmondás fontosságára. Ennél fogva az is teljesen érthető, hogy a pragmatikus amerikai gondolkodásból kifolyólag itt áldoznak a legtöbbet a kiskorúak megbízhatóságának tudományos vizsgálatára. Ezeknek a vizsgálatoknak a legtöbbje a konceptuális fejlődés kérdését, az eskü alatt tett vallomások megbízhatóságát, az emlékezeti rekonstrukcióból származó téves emlékeket és az emlékek manipulálásának lehetőségeit vizsgálják. Ez utóbbi két kérdéskör is külön említést érdemel.

A kiskorúak esetében nagyon gyakran megfigyelhető az, hogy a válaszukat a felnőttek által adott hívóingerek köré strukturálják. Ezért is kell a megbízhatóság problémájához árnyaltan viszonyulni. Vagyis, ahhoz, hogy a gyermek egy eseménynek az igaz és megbízható leírását adja, megfelelő módon kell kérdezni is őt. A szándék nélküli 
vagy szándékosan rosszul feltett kérdések hibás rekonstrukciót vagy hibás következtetéseket eredményezhetnek. A kérdezés kiváltsága egyfajta hatalmat kölcsönöz, de ez fordítva is igaz, vagyis akinek hatalma van, az kérdezhet [8]. Márpedig egy tanúvallomás idegen helyzetében nagy a kockázata annak, hogy a gyermek úgy érezze, hogy a felnőtti hatalomnak kiszolgáltatott. A kérdezés technikája tehát a szó szoros értelmében perdöntő lehet. Azok a szakemberek, akik ilyesfajta kihallgatásokat vezetnek, azt ajánlják, hogy a gyermekhez intézett kérdéseket előzze meg a szabad felidézés. Ez az eljárás már kisgyermekeknél is használható, hiszen viszonylag pontosan idéznek fel dolgokat. A viszonylagos pontosság azt jelenti, hogy figyelembe kell venni azt, hogy a stressz a szabad felidézésre úgy hat, hogy elősegíti az esemény központi elemeinek előhívását, de a mellékesnek ítélt vagy összetett jelentésű aspektusokra zavaróan hat. Ebből kifolyólag a szabad felidézést követően nyílt kérdések használata ajánlott. Például, a személyleírás kapcsán úgy kérdezünk, hogy „milyen színű felsőt viselt?” és nem azt kérdezzük, hogy „fekete felső volt rajta?”. Ez utóbbi, zártnak nevezett kérdések kerülendőek, mert szuggesztívek, vagyis a gyermek, hogy megfeleljen a felnőtti elvárásoknak gyakran ad ezekre, hibásan, igenlő választ. Ez az igenlési tendencia fordítottan viszonyul az életkorhoz, vagyis a kisebb gyermekeknél gyakoribb, mivel azt gondolhatják, hogy minden kérdésre válaszolniuk kell, még akkor is, ha nem biztosak a válaszban, továbbá hiszik azt, hogy a felnőtt sugallata kell érvényesüljön, mert úgy gondolják, hogy ők a nagyobbak, ezért jobban tudják.

Jó esetben a gyermek ismétlődően ugyanazokat az információkat szolgáltatja, azaz konzisztensen beszél. Hogyha a beszámolója változik időről időre, akkor inkonzisztenciáról beszélünk. Ez nem feltétlenül ellentmondásos információ. Tételezzük fel, hogy a gyermek részt vesz egy nyári táborozáson, ahol horgásznak, kirándulnak és tábortüzet raknak. Ha a gyermek folyamatosan arról számol be, hogy horgászott, akkor konzisztens a beszámolója, ha viszont egyszer azt mondja, hogy horgászott, utána azt, hogy kirándult, azt követően azt, hogy tábortüzet raktak, akkor a beszámolója inkonzisztens, de nem ellentmondásos, mert mindegyik esemény megtörtént. Ellentmondásos akkor lenne, ha azt mondaná, hogy kirándult, de egyebet semmit. A konzisztencia növelése érdekében már érdemes zárt kérdéseket is feltenni, megkérdezhetjük, hogy tábortűz volt-e vagy sem. Ez egy specifikus kérdés, ami megjelöli, hogy mit kellene felidézni, bár a válasz óvatosan kezelendő, mert szuggesztív. A szabad felidézés és nyílt kérdés, mivel rugalmas válaszadást biztosítanak, az inkonzisztenciát növelik, a zárt kérdés behatárolja a választ és a konzisztenciát növeli. A kérdezés technikája ezért korántsem egyszerü, és megkívánja az életkori sajátosságok maximális figyelembevételét.

Mi történik abban az esetben, hogyha a gyermek válaszai nem konzisztensek és ezen túlmenően még félrevezetőek is? Azt gondolnánk, hogy csupán annyi a probléma, hogy az általa szolgáltatott információk nem használhatóak. Ennél súlyosabb a helyzet, mert a felnőttek, bármennyire is meglepőnek tűnik, nem túl jók a blöffölő gyermek leleplezésében. Nehezen veszik észre, hogy a gyermek mikor mond igazat és mikor hazudik, így a hamis információt is könnyen igazként kezelik. Az őszinteség vizsgálatára igen egyszerü próbákat használnak, amelyekben a gyermeknek uralkodnia kell magán, hogy ne csaljon egy könnyen megszerezhető információ céljából. A kísérletvezető és a neki háttal ülő gyermek együtt játszanak. A gyermeknek az a feladata, hogy találja ki, hogy a felnőtt milyen tárgyat rejteget. A pontos találatot jutalommal erősítik meg. Hogy a találgatás könnyebben menjen, a felnőtt rövid szóbeli leírást ad a tárgyról, majd a gyermek megpróbálja kitalálni, hogy miről van szó. Amikor a céltárgy következne a játékban, akkor a kísérletvezetőt egy telefonhívás ürügyén kihívja a teremböl egy másik felnőtt. Mielőtt kimenne, figyelmezteti a gyermeket, hogy távollétében nehogy meglesse a tárgyat. A céltárgy egy ismert babafigura, nevezzük Micimackónak. A gyermeknek tehát uralkodnia kell a kíváncsiságán és a jutalom utáni 
sóvárgásán, hogy ne lesse meg Micimackót. Viselkedését detektívtükrön vagy beépített kamerán keresztül figyelik. A kísérletvezető a visszatérte után mindig megkérdezte a gyermektöl, hogy lesett-e, továbbá azt is, hogy mit gondol, hogy mi az elrejtett tárgy.

$A z$ „ellenállás a kísértésnek” helyzetben a szakértőnek nem nevezhető felnőttek képtelenek a nem verbális jelzések alapján kiszürni a csaló gyermekeket, bár a videofelvételeken voltak biztosan azonosítható jelei ennek, például hosszabban és szélesebben mosolyogtak mint az őszinte társaik [9]. Azt gondolnánk, hogy azok a felnőttek, akik szakmai szinten is napi kapcsolatban állnak a csalókkal, mint a rendőrök és vámtisztek, jobban teljesítenek és nagyobb arányban képesek leleplezni a csaló gyermekeket.

Egy vizsgálatban a pszichológusok ennek próbáltak utánajárni [10]. Kiindulópontként az „ellenállás a kísértésnek” helyzetet követöen négyszemközti beszélgetést folytattak a gyermekekkel a rendőrök, a vámtisztek és a kontrollként használt egyetemi hallgatók, azzal a céllal, hogy azonosítsák a csalókat. Érdekes módon azonban egyik csoport sem bizonyult jobbnak a másiknál, és a leleplezett csalók aránya is jelentéktelen volt. Ezt követően két másik, módosított kísérleti helyzetben is lemérték a hatékonyságot. Egyik esetben az alaphelyzet egy morális jellegű beszélgetéssel egészült ki, amelyben az igaznak és hamisnak lenni állapotokról beszélgettek a gyermekekkel, egy másik helyzetben pedig megígértették a gyerekekkel, hogy igazat mondanak. Ez esetekben mindhárom felnőtt csoport több csalót volt képes leleplezni, de a lebuktatott gyermekek aránya így sem haladta meg a 70\%-ot, vagyis a csalók 30\%-a megúszta a helyzetet. Ezek az arányok az igazságszolgáltatás keretei között értelmezve egyáltalán nem megnyugtatóak, egyetlen komoly bíróság sem vállalna be ekkora tévedési lehetőséget. A dolgok pikantériája, hogy a néhány esetben a rendőrök rosszabbul is teljesítettek, mint a vámtisztek vagy az egyetemisták. Ezt azzal magyarázzák, hogy a rendőrök többnyire hosszas lefolyású vizsgálatokat vezetnek és ritkán kapnak visszajelzést gyanúik beigazolódásáról. Az előállítások és letartóztatások rendje nem feltétlenül jelenti a bünösség megállapítását. Ez persze nem hangzik megnyugtatóan egy olyan generáció számára, akik nap mint nap a televízióban, részleteikben is lenyűgözően kimunkált akciófilmeken azt látják, hogy a rendőr mindig kézre keríti a rossz fiúkat. A vámtisztek hatékonyabbak voltak a rendőröknél, és ezt azzal magyarázzák, hogy napi rendszerességgel, minimális információ birtokában kell gyorsan eldönteniük azt, hogy valakit milyen fokú ellenőrzésnek vetnek alá.

$A z$ ilyenszerü vizsgálatok mindenképpen figyelmet érdemelnek, mert a felnőttek gyakran hajlamosak legyinteni a gyermekek beszámolóira és véleményére, annak valóságtartalmát intuitív módon értékelni. Ezzel szemben, indokolt esetben, mint amilyen például a vallomástétel, különösen figyelni kell a morális fejlődés jellemzőire és az igazság és hazugság erkölcsi fogalmainak tisztázására, arra, hogy expliciten felszólítsuk a gyermeket az igazmondásra, illetve a kérdezés technikájára. Mindemellett, azt gondoljuk, hogy a gyermek megismerésének és különösen a megtévesztő viselkedés megértésének nélkülözhetetlen feltétele az, hogy a felnőttek kellő alázattal és kíváncsisággal viszonyuljanak a gyermekhez. Megérdemlik, mert ebben is sokkal bölcsebbek, mint azt a legtöbb felnőtt gondolná. A felnőttek tehát alábecsülik őket, tulajdonképpen önmagukat tévesztik meg azzal, hogy butának látják a gyerekeket.

\section{Az önmegtévesztés csapdája}

Az ember utódjának, születése után, hosszú évekre nyúló gondozásra van szüksége, rengeteg tudást kell elsajátítania, melynek alapjait a családban zajló szocializáció jelenti. Azért van szükség ilyen hosszú időre, mert sok mindent kell megtanulni, és ez a tudás szervezettségében és tartalmában is igen komplex. A fajra jellemző viselkedés elsajátításának hossza közvetlenül jelzi azt, hogy mennyire értelmes az adott faj. Vannak olyan élőlények, amelyeknek viselkedésmintái igen bonyolultak, de rugalmatlanok, mert 
szabályozásuk teljes mértékben örökletesen, azaz gének által történik. Ez azt jelenti, hogy nem kell tanulniuk a viselkedést. Emberi léptékkel mérve látszólag okosan viselkednek, de a valóságban nem kell érteniük azt, amit tesznek. Vegyük példának a méhek táncát. $A$ kaptárba visszatérő méhek a függöleges falon körkörös mozgást végeznek és közben potrohukat rázzák, ezzel jelezvén társaiknak, hogy milyen irányba és mennyit kell repülniük a lelőhely megtalálásáig. A dolgozók maguk is átveszik ezt a táncot, néhányszor megismétlik és utána repülnek el a megadott irányba. Bármennyire is bonyolult ez a kommunikációs minta, a méheknek nem kell ezt tanulniuk, hiszen ennek minden egyes eleme egy génekben rögzített viselkedés. A rugalmatlanságát az jelzi, hogy ha a tánc folyamatát bármilyen váratlan esemény megzavarja, akkor az egész viselkedés újrakezdődik, sosem folytatja onnan a felderítő, ahol abbahagyta. A rögzült viselkedés egyben azt is jelenti, hogy nem fejleszthető képességröl van szó, vagyis nincsenek újonc és tapasztalt táncosok, a gyakorlásra érzéketlenek.

Ha az emberi viselkedést vesszük górcső alá, akkor ennek ellenkezőjét látjuk. Bár természetesen minden egyes emberi viselkedés mögött ösztönök húzódnak meg, mégis óriási jelentőséget nyer a tanulás. A tanulás képessége teszi a viselkedést rugalmassá, átszervezhetővé. Képzeljük el, hogy azt látjuk, hogy egy ember a konyhában véletlenül a saját ingére önti a paradicsomszószt, feláll, bemegy a fürdőszobába, leveszi az ingét, vizet tölt egy tálba, mosószert tesz bele, majd elkezdi kimosni a foltot. Amikor a folt eltávolodott, akkor kicsavarja az inget, felteszi a szárítókötélre, majd megtörli egy törülközővel a kezét, a szekrényhez megy, új inget választ magának és magára ölti. Hogyha ez a viselkedés csakis gének által szabályozott minta alapján zajlana, akkor minden „piros folt a mellen” helyzet kiváltaná ezt a viselkedést, és csak akkor érne véget, ha a mozzanatok a megfelelö sorrendben végigjátszhatóak. De mi történne, hogyha valamilyen akadály merülne fel? Mondjuk, hiányozna a törülköző a törülközőtartóról. Akkor az ember addig értelmesnek hitt viselkedése hirtelen nagyon furcsává válna. Miután nem találja a törülközőt, visszaölti az ingét, kimegy a konyhába, újra magára önti a paradicsomszószt, bemegy a fürdőszobába, leveszi az ingét, vizet tölt a tálba, mosószert tesz bele, kimossa a foltot, és mindezt addig próbálná, amíg sikerrel járna, ha kell, akár végkimerülésig.

A rugalmasság azt jelenti, hogy a meglévő viselkedésséma módosítható. Ha nincs a törülköző a helyén, akkor újat vesz az ember a szekrényböl, vagy papírt használ, vagy egyszerüen nem törli meg a kezét. Az emberi viselkedés igen nagyfokú rugalmassággal jellemezhető, azaz képesek vagyunk tapasztalatunk nyomán igen gyorsan felismerni és mérlegelni helyzeteket, majd ezekhez hatékonyan igazodni, akár úgy is, hogy az előzőekhez képest újszerüen járunk el. A világról alkotott tudás tehát összehasonlíthatatlanul más és több mint egy előprogramozott méhecske esetében. Az ember utódjának rengeteget kell tanulnia, amíg a világról olyan tudásbázist alakít ki, ami az önálló és sikeres életvitelt lehetővé teszi. Ez a legkülönbözőbb emberi kultúrákban is mindenhol meghaladja az egy évtizedet, de a nyugati típusú társadalmakban sokkal hosszabb. Az intenzív tanulás időszakában a felnőtt és gyermeke közötti kapcsolat aszimmetrikus függőségi kapcsolat, vagyis a szülő gondoskodik gyermekéről, de irányítja is őt, ő a domináns fél.

Ha a pedagógia történetét tanulmányozzuk, észrevehetjük, hogy az írásbeliség kialakulása óta a gyermekek nevelésének kérdése minden jelentősebb kultúrában felvetődik és foglalkoztatja a kor bölcselőit. A görög és római nevelésben a fiúk fegyelmezett, bátor és jó fizikai erőnléttel rendelkező polgárokká formálása volt a cél. Katonai és politikai ismereteket tanultak, s mindenfajta pedagógiai beavatkozást a szigor légköre lengett be, hiszen a tanulás elengedhetetlen feltételének tekintették felnőtteknek való engedelmességet. A felnőtt akaratának korlátlan érvényesítése jellemzi a korai és késői középkort is, mert a gyermeket eredendően rossznak tartották, és a cél az volt, hogy rákényszerítsék őt a jónak vélt útra. Mivel a gyermek nem képes a jó és rossz 
megkülönböztetésére, fontos, hogy a felnőtt segítse ebben, és megakadályozza az eredendően bűnös természet felülkerekedését. Az értelmi fejlődés velejárójaként tekintették a bűnre való fogékonyságot, ami azt jelentette, hogy a büntetésen és verésen alapuló szigor végigkísérte minden ember fiatal éveit. Meg kellett akadályozni, hogy olyan dolgokon gondolkodjanak, melyek bűnnek tekintett cselekvésbe torkolhatnak. Valószínüleg ez a középkori időszak lehetett a gyermeknevelés legsötétebb kora is.

A reneszánsz és humanizmus beköszöntével a gyermeki sajátosságok és az egyéni adottságok fontosságára irányul a figyelem, a civilizált és erkölcsös ember alakításának szándékával. A testi fenyítéssel betört szolgalelkü gyermek helyett a szeretetre és gyengédségre épülő nevelést hangsúlyozzák a humanista gondolkodók, de tévedés lenne azt hinni, hogy ezek a gondolatok széles körben meghallgatásra találtak. A szélesebb és tudatlanabb rétegekben a testi fenyítés és a gyermek megalázása maradtak a legkézenfekvőbb nevelési eljárások.

Ez a helyzet még a felvilágosodás korában sem változott meg gyökeresen, annak ellenére, hogy már olyan gondolatok is megfogalmazódtak, hogy a pedagógia célja a gyermek boldogulása. A XIX. századtól a gyermekek taníttatásának gondolata már sokkal népszerübb lett, mint korábban bármikor, gombamód szaporodtak az iskolák, és a családban zajló nevelés is módszeresebbé vált. Nagyon sok olyan gyermeknevelési kézikönyv jelent, ami gyakorlati tanácsokat tartalmaz szülök részére, de ezeket fellapozva az új gyermekszemléletet még mindig csak csíráiban találjuk. A tudás pozitív felértékelése könnyen tapintható, de legalább ennyire az is, hogy a nevelés elengedhetetlen feltétele a szigor, és a puhányság legkisebb jele is megvetendő. Emlékszem, hogy amikor serdülőként kezembe került az egyik dédnagyanyám több mint százéves jutalomkönyve, ami a gyermekek helyes viselkedéséröl szól, mennyire megdöbbentett annak poroszos hangulata. Tisztán megmaradt emlékezetemben az egyik illusztráció, amelyiken három rongyos gyermek és egy kutya kucorog egy rozoga esernyő alatt. Alatta pedig a szövegben az áll, hogy „Ugyan mióta lettetek ilyen anyámasszony katonái, hogy egy kis esőtől már halálra ijedtek és menhely alá igyekeztek menekülni. Nekünk régi időben azt mondta apánk, mikor esett az eső: aló gyerekek, ki az udvarra, az eső nem árt, meg kell azt szokni, attól nő a gyermek! Ti pedig összebújtok, s még kóczos kutyátokat is oda vonjátok s négyesben igy szemlélgetik az Istenáldás hullását...No, aló ki a rozzant ernyő alól! Nem vagytok cukorból, hogy elolvadjatok. Okos gyermek nem kényezteti így magát". Manapság természetesen tiltanák a szülök, hogy a gyermekük olymódon eddze magát, hogy üldögél a szakadó esőben, és mélyen megvetnék, vagy feljelentenék azt a szülőt, aki arra biztatja gyermekét, hogy áztassa magát, mert az erősít.

Az ilyesfajta nevelési princípiumok az elmúlt évszázadban lassan kikoptak, az általános jólét növekedésével, a gyermeki életeket korábban tizedelő járványok visszaszorításával és a nevelésnek közüggyé tételével elöretört a gyermekközpontú szemlélet. Ennek szellemében a modern pedagógiában szakítani szerettek volna az autoriter hagyományokkal, és igyekeztek az individuum érvényesülésének minél nagyobb teret biztosítani. Kisebb-nagyobb sikerrel, de a teljes siker valószínüleg örökre elodázódik. Ennek bizonyára nem egyetlen és pontosan körülhatárolható oka van, és nem is csak a jelen történelmi kontextusában válik érthetővé. Ennél mélyebbre és régebbre kell visszanyúlni, az emberiség történelmében végig jelenlévő generációs csaták mozgatórugóit kell megérteni.

$\mathrm{Az}$ emberi társadalmak természetes állapota $\mathrm{az}$, hogy a felnőtt generációk igyekeznek konszolidálni és konzerválni hatalmukat, míg a fiatalabbak igyekeznek kikezdeni ezt, ellenállást tanúsítanak, lázonganak, gyengítik a hatalmon lévők pozícióit, mert ők maguk áhítoznak ezekre. Nem véletlen, hogy a gyökeres történelmi változások, az újító forradalmak mögött mindig az ifjúságot találjuk. Csányi Vilmos, a híres magyar 
viselkedéskutató az egyik szellemes írásában az iskola intézményét vizsgálja az etológus szemével, és arra világít rá, hogy ennek társadalmi szerepe preadaptációs jellegében mutatkozik meg [11]. A preadaptáció azt jelenti, hogy valamilyen hatásra megjelenik egy új tulajdonság, de ennek igazi haszna nem is az, amiért eredetileg megjelent, hanem a későbbi változások nyomán derül ki.

A mindenkori iskola alapvetően egy konzervatív szerveződés, olyan értékeket közvetít, amelyeket a felnőtt generáció vall magáénak, tehát gyakorlatilag itt próbálja a szabályrendszeréhez igazítani a fiatalokat. Ez azonban korántsem könnyű feladat, hiszen a nebulók legtöbb esetben egészen más dolgokra lennének kíváncsiak, szívesebben csinálnának egyebet, mint amiért az iskolában ücsörögnek. Az iskola tehát az adott társadalom kicsinyített mintázata, annak generációs érdekellentétét tükrözi. A nehezen betörhető vagy hajthatatlan diákság tulajdonképpen egy roppant fontos funkciót gyakorol, az ellenállás körmönfont formáit a zsarnoksággal szemben, amelyek majd alkalomadtán hasznosíthatóak a társadalmi változások rendjén. Így lesz az iskola egy olyan intézmény, melynek eredeti funkciója a tudás közvetítése, de evolúciós szempontból megítélve a kulturális preadaptációja az újító forradalmaknak. Nem véletlen tehát, hogy a felnőttek mindent megtesznek azért, hogy az ifjúi lendületet kezelhetővé tegyék: naivnak, meggondolatlanoknak, forrófejüeknek nevezik és lehetőség szerint meg is büntetik őket. Azokat viszont akik lojálisak és hajlandóak a kiépített intellektuális intézményeket szolgálni, lehetőség szerint megjutalmazzák, elismerik és általuk példát statuálnak a lázadók ellenében. Nem kell különösen éles szemü megfigyelőnek lenni ahhoz, hogy észrevegyük, hogy a tanárok mindig a könnyen alkalmazkodókat, vagyis az intelligens tanulókat kedvelik és nem a nehezen alkalmazkodó, izgága, kreatív gyermekeket. Az előbbiek, tudnak úgy viselkedni, ahogy azt pontosan elvárják tőlük, az utóbbiak viszont, non-konformista viselkedésükkel, a saját generációjuk sürgető tenni akarásának a megtestesítői.

A generációs problémák és általában a gyermek kezeléséhez a felnőttek újra az önmegtévesztés stratégiáját vetik be. Ennek az a lényege, hogy a gyermeket nem kell „komolyan” venni, mert a gyermek nem „komoly” felnőtt. Keveset tud a világról, azt is sokszor hibásan, meggondolatlan és megfontolatlan, döntésképtelen, impulzív ösztönlény. Ebből már természetszerüen következik az, hogy irányításra és szabályozásra szorul, vagyis a felnőttnek felelőséget kell vállalnia érte. A felelősségvállalás gyakorlásához viszont hatalmi pozíció szükséges. Így lesz a hatalom fenntartásának tudattalan eszköze az önbecsapás. Ha a nevelés történetét vizsgáljuk, akkor nehéz nem észrevenni, hogy mennyire öncélúan nevelték gyermekeiket a mindenkori szülök és mennyire semmibe vették a gyermeki természetet. Szinte az érthetetlenség határát súrolja, hogy mennyire nem érdekelte a felnőtteket, hogy mit észlel, gondol és érez a gyermek a megélt világgal kapcsolatosan.

Sajnos, még akkor sem jobb a helyzet, hogyha a gyermekre irányuló kutatásokat elemezzük. A fejlődéslélektanban rengeteg vizsgálat kifejezetten arra fektet hangsúlyt, hogy mit nem képes a gyermek azon a szinten teljesíteni mint a felnőtt, és e szerencsétlen viszonyítás folytán azt hinnénk, hogy az egyedfejlődés nem más, mint a tökéletlenségtöl a tökéletességig vezető út. Klasszikus megközelítésben a gyermek csak elszenvedi a világ történéseit, de nem képes megérteni és befolyásolni ezeket. Nemritkán a gyermekhez intézett kérdések oly módon fogalmazódnak meg, hogy eleve beleterelik egy hibás válaszba, és amit kognitív deficitként értelmez a szakma. Például, ha a Piaget által vizsgált mennyiség-konzervációt emeljük ki, az alanynak azt kell eldöntenie, hogy két ugyanannyi érmét tartalmazó halmaz melyikében van több, amikor az egyikben ezeket tömörítve, a másikban széthúzva, hosszabb sorban látja. Nyilvánvalóan a kérdésfeltevés azt sugallja, hogy az egyik sorban több van, hiszen a felnőtt azt kérdi, hogy melyik sorban van több. Ha viszont a gyermek a kérdés szellemében dönt, és különbséget keres, akkor azt a 
kísérletvezető hibás válaszként könyveli el, vagyis alacsonyabb kognitív szintre sorolja a gyermeket.

Csupán az utóbbi három-négy évtizedben derült fény arra, hogy mennyire félreismertük a gyermeket és mennyire alábecsültük kognitív felvértezettségét. Mindinkább bizonyosnak látszik, hogy a csecsemő már születése pillanatában kompetensebb, mint azt gondoltuk valaha, s számára a világ nem kaotikus zürzavar, hanem inkább rendezett színtér. Kiderült, hogy van elképzelésük arról, hogy mi is egy tárgy, megértik a szilárdság fogalmát, képesek előre jelezni a tárgy mozgási pályáját, és tudják, hogy ennek a pályának folytonosnak kell lennie. Vagyis vannak naiv fizikai ismereteik. Ezen túlmenően viszont a naiv pszichológiával sem állnak rosszul. A néhány hónapos csecsemők már képesek másoknak szándékot tulajdonítani és ennek megfelelően anticipálni azok viselkedését, néhány éves korukban pedig már egészen jó elmeolvasók, megértik, hogy mások fejében ugyanarról a dologról egészen eltérő reprezentáció alakulhat ki. Ez a tudás pedig a létező tudások legnehezebbike.

Mivel magyarázható akkor, hogy a felnőttek vonakodnak elismerni ezeket a bölcsességeket? Valószínüleg ugyanarról a fegyverről van szó, mint amit az élővilág más fajaival szemben érvényesítenek. Önmegtévesztés, ami felruházza az embert az utódai feletti korlátlan hatalommal. Ami elönyösnek bizonyul interspecifikusan, az müködik intraspecifikusan is a generációk közötti kapcsolatban, azzal a különbséggel, hogy itt nincsen behozhatatlan előny a hatalmasok számára, mert az utódok kitartó trónkövetelő munkája előbb-utóbb célra vezet.

\section{Irodalomjegyzék}

[1] Vygotsky, L. S. (1978): Mind in society: The development of higher psychological processes. Harvard University Press, Cambridge

[2] Sternberg, R. J. (1985): Beyond IQ: A Triarchic Theory of Intelligence, Cambridge University Press, Cambridge

[3] Mucchielli A. (2000): L'art d'influencer. Analyse des techniques de manipulation. Armand Colin, Paris

[4] Leach, A-M., Talwar, V., Lee, K., Bala, N., Lindsay, R.C.L. (2004): „Intuitive” lie detection of children's deception by law enforcement officials and university students. Law and Human Behavior, 28(6), 661-685.

[5] Talwar, V., Lee, K., Bala, N., Lindsay, R.C.L. (2002): Children's conceptual knowledge of lying and its relation to their actual behaviors: Implications for court competence examinations. Law and Human Behavior, 26(4), 395-415.

[6] Talwar, V., Lee, K. (2002): Development of lying to conceal a transgression: Children's control of expressive behavior during verbal deception. International Journal of Behavioral Development, 26(5), 436-444

[7] Talwar, V., Lee, K., Bala, N., Lindsay, R.C.L. (2002): Children's conceptual knowledge of lying and its relation to their actual behaviors: Implications for court competence examinations. Law and Human Behavior, 26(4), 395-415.

[8] Herwig-Lempp, J. (2002): A helyes kérdezés módja. Pszichoterápia, 11(6), 397-406.

[9] Talwar, V., Lee, K. (2002): Development of lying to conceal a transgression: Children's control of expressive behavior during verbal deception. International Journal of Behavioral Development, 26(5), 436-444.

[10] Leach, A-M., Talwar, V., Lee, K., Bala, N., Lindsay, R.C.L. (2004): „Intuitive” lie detection of children's deception by law enforcement officials and university students. Law and Human Behavior, 28(6), 661-685.

[11] Csányi V. (2007): Ironikus etológia: Az iskola (Evolúciós áttekintés). In Gábor Gy., Márton L., Vásárhelyi M., Volosin H. (szerk.): A párizsi toronyőr, Budapest, Pallas Kiadó, 126-131. 